\title{
Strategy for Improving the Performance of Language Education Institutions Using SWOT Analysis: Case Study of Arabic Language Education at Ma'had ABC
}

\author{
Dean Yulindra Affandi ${ }^{*}$, Dasril Guntara ${ }^{2}$ \\ ${ }^{1,2}$ Finance and Banking, Vocational Education Program, Universitas Indonesia \\ *Email: bpkdean@gmail.com
}

\begin{abstract}
At Ma'had ABC, a religious education institution, the Arabic language program plays an important role, especially in Islamic da'wah and diplomatic relations between Indonesia and Saudi Arabia. Since 9/11, however, the development of the Arabic language program has stalled due to the decline of aid from Saudi Arabian education funds. In order to improve the performance of educational institutions like Ma'had ABC, appropriate and effective strategies are needed. Strategy preparation is done by identifying internal and external factors (SWOT analysis), which are then analyzed using IFE, EFE, and IE matrix instruments. The data used in this research consist of primary and secondary data processed through a content analysis method. The results show a need to increase teachers' capacity for school management, especially in the area of finances, increase the capacity of educators and administrative staff of education, and develop a more exciting method of teaching and learning to increase student participation.
\end{abstract}

Keywords: IFE, EFE, IE, SWOT

\section{Introduction}

Ma'had ABC is an Arabic language education institute founded in Lombok in 2002. Its establishment coincided with the establishment of Ma'had XYZ in Cibinong. Ma'had ABC offers a D1 program of Arabic language, which uses the LIPIA curriculum that has been adjusted to the L-DATA curriculum. The handbooks for the program, as teaching materials, are from Saudi Arabia. In addition, a book titled Khulashah Nurul Yaqin is used as a supplementary source to facilitate students' understanding of materials presented in Arabic.

At the beginning of the establishment, the ma'had had a large number of applicants that reached up to 200 students. About 60 students, divided into two classes, actively studied up to graduation. Yet every year, there was a decrease in the number of applicants, and this affected the matriculated students. On average, only $40 \%$ of students who applied finished the year. At first, Ma'had ABC offered only an ikhwan (male) class, but starting in 2016, an akhwat (female) class was added. In the first year the akhwat class opened, 50 students registered. The retention rate from registration to completion was approximately $60 \%$. At this time, there were more students in the akhwat class compared to the ikhwan class. For instance, in 2017-2018, the ikhwan class had 12 students, whereas the akhwat class had 29 students.

Funds from NAMA, an institution in Saudi Arabia, greatly affect the operational and student enrollment rates at Ma'had $\mathrm{ABC}$. When the school was first established, students received a $\$ 7$ learning fee subsidy. In the early stages, grants were used solely for supporting students and operational learning processes. Since the location in Lombok was difficult to access, teachers and administrators often traveled there on foot. The provision of vehicles, language labs, and mosques was fully funded by NAMA.

Apart from the funds from NAMA, operating costs at Ma'had ABC were covered by funds from institutions and community figures in Lombok. As of this year, the teachers have not received their salary for some months.

Based on the interviews, the main problem facing Ma'had ABC is the stalled flow of funds from Saudi Arabia that has been ongoing since 9/11. As a result, many school activities that are hampered, and teacher salaries remain unpaid. Then, in 2018, one of Saudi Arabia's financial institutions announced it would send funds to Ma'had ABC if the school can develop a work program with strategies for curriculum development, finance, marketing, human resources, and operations, taking into account its priority problems, strengths, and opportunities. 


\section{Methodology}

This research can be categorized as applied research because the findings can be used as input for the Ma'had ABC Language Institute to optimize its strategy development.

The study uses both quantitative and qualitative methods. Purposive sampling and three types of data collection (or sources of evidence) were employed: survey (questionnaire), documentation, and interviews.

\section{A. Survey}

The main data were collected through a survey questionnaire (structured interview guide) containing items about the concept of "satisfaction." The sampling technique used the total population. This was possible because the survey object coverage is not too large but quite heterogeneous.

B. Interviews

Interviews were carried out to obtain in-depth information from key participants to explore their perceptions about the level of job satisfaction of employees and partners at government institutions.

C. Focus Group Discussion

Focus group discussions (FGDs) were used to gather qualitative data about the program implementation process, including challenges and problem solving, perceived impacts, program sustainability, and suggestions for improving future programs.

Table 1 Number of Participants for the Qualitative Approach

\begin{tabular}{|l|l|c|}
\hline Role & Data Collection Method & $\begin{array}{l}\text { Number } \\
\text { Participants }\end{array}$ \\
\hline Head of the Foundation & In-depth Interview & 1 \\
\hline Headmaster & In-depth Interview & 2 \\
\hline Teachers & Group Interview & 2 \\
\hline Management Staff & Group Interview & 2 \\
\hline
\end{tabular}

Table 2 Number of Participants for the Quantitative Approach

\begin{tabular}{|c|c|c|}
\hline Sampling Unit & $\begin{array}{c}\text { Number of Participants } \\
\text { (Questionnaire Responses) }\end{array}$ & Method Description \\
\hline All Students & 344 & $\begin{array}{c}\text { Total sampling: } \\
\text { Questionnaires were } \\
\text { distributed to all students }\end{array}$ \\
\hline
\end{tabular}

\section{Data Analysis}

SWOT analysis is a simple tool to examine an organization's strengths, weaknesses, opportunities, and threats. The simplicity of this tool is part of the reason many types of organizations have been using it for decades. The SWOT tool prepares organizations to identify strengths to develop, weaknesses to mitigate, opportunities to seize, and threats to avoid. It can be used for early brainstorming or to guide more intensive strategic discussions - internally in a housing and community development organization or externally to bring input from stakeholders. A SWOT analysis can help collect and organize information to explore new opportunities, make decisions about new strategies, identify areas for change, and refine and redirect current efforts with new solutions.

The SWOT also brings out the major issues to address in the strategic plan. These strategic issues are few in number, but they have a great effect on the organization's performance. When they are clearly identified and described, the planning team can devise strategies to deal with them. The SWOT framework - a two-by-two matrix - is best completed in a group with key members of the team or organization present. First, it is important to be set what the policy change objective is and what team or organization the analysis is being carried out on. Then, the process begins with a brainstorm of ideas, which are subsequently honed down and explained further in discussion.

An assessment of internal capacity helps identify where the project or organization is currently: e.g., the existing resources that can be used immediately and current problems that will not go away. It can also help 
identify where new resources, skills, or allies will be needed. When thinking of strengths, it is useful to think of real examples of success to ground and clarify the conversation.

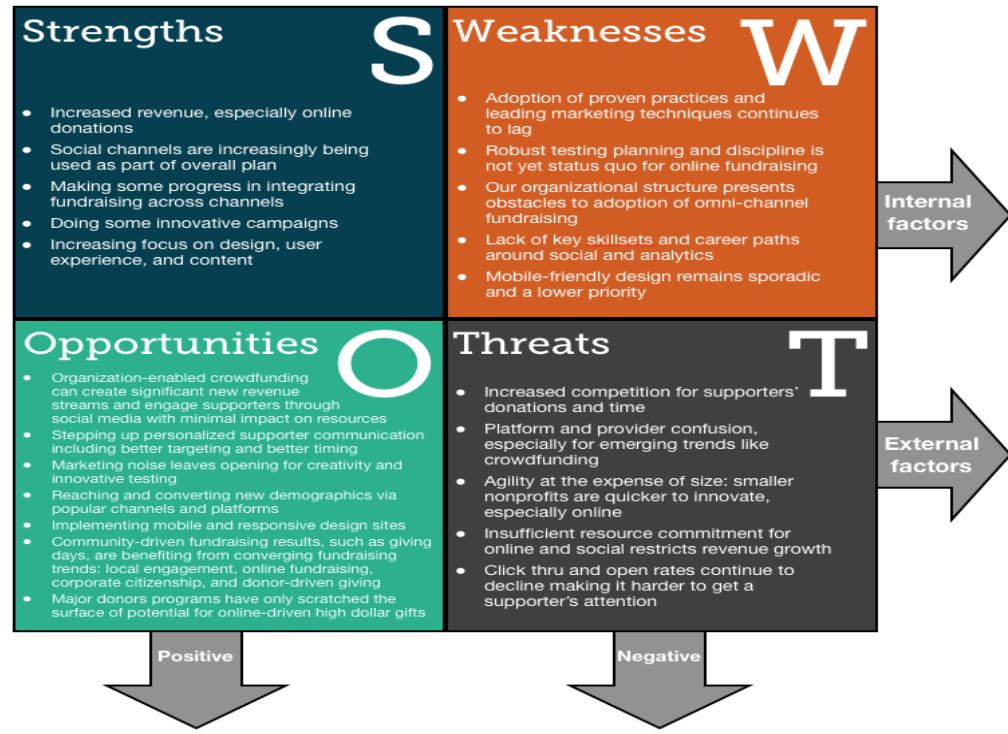

Figure 1. SWOT Matrix (example).

Source: https://kimbia.com/fundraising-organization-swot-analysis-2014/

An assessment of the external environment tends to focus on what is going on outside the organization, or areas which are not yet affecting the strategy but could - either positively or negatively. Figure 1 summarizes some of the subject areas that might need consideration under both internal and external factors. These can be used as topic headings in small break-out groups (which is a good idea if the group is larger than about eight people).

Back in plenary, it is often useful to rate or rank the most important strengths and weaknesses (e.g., with symbols:,+++ , and 0 ). In a larger group, participants might like to assign their own scores, such as by giving a certain number of sticky dots. The results can then be discussed and debated. It is important to keep an eye on possible actions or solutions that emerge and to conclude with an action-oriented discussion. For instance, the group might consider questions such as, "How can our group build on strengths to further our aim and strategy?" or "What can be included in the strategy to minimize our weakness?"

SWOT analysis is a versatile tool that can be returned to at many different stages of a project, such as to structure a review or provide a warm-up discussion before forward planning. It can be applied broadly, or a small sub-component of the strategy can be singled out for detailed analysis. The SWOT often forms a useful complement to a stakeholder analysis. Both are good precursors to Force Field Analysis and Influence Mapping.

\section{Results}

Ma'had ABC offers a D1 program of Arabic language, which uses the LIPIA curriculum that has been adjusted to the L-DATA curriculum. The handbooks for the program, as teaching materials, are from Saudi Arabia. In addition, a book titled Khulashah Nurul Yaqin is used as a supplementary source to facilitate students' understanding of materials presented in Arabic.

At the beginning of the establishment, the ma'had had a large number of applicants that reached up to 200 students. About 60 students, divided into two classes, actively studied up to graduation. Yet every year, there was a decrease in the number of applicants, and this affected the matriculated students. On average, only $40 \%$ of students who applied finished the year. At first, Ma'had ABC offered only an ikhwan (male) class, but starting in 2016, an akhwat (female) class was added. In the first year the akhwat class opened, 50 students registered. The retention rate from registration to completion was approximately $60 \%$. At this time, there were more students in the akhwat class compared to the ikhwan class. For instance, in 2017-2018, the ikhwan class had 12 students, whereas the akhwat class had 29 students.

This scientific article will examine alternative strategies that can be applied to improve the performance of Ma'had ABC by using the Internal Factor Evaluation (IFE), External Factor Evaluation (EFE), and InternalExternal Matrix (IE) instruments. The IFE matrix is a tool for identifying strengths and weaknesses in business functional areas. The EFE matrix serves to identify external factors of opportunities and threats that affect a 
business (David, 2015), although, in this case, the organization is Ma'had ABC. The third matrix is the IE matrix, which is used to identify the right strategy to be applied based on IFE and EFE values.

Below are the results of the analysis of the strengths and weaknesses of Ma'had $\mathrm{ABC}$ as obtained from interviews and FGDs with the ma'had board at the central level as well as at the regional level:

\section{Strengths}

The materials are from a proven curriculum adopted from LIPIA.

The school already has a mosque.

The teachers are experienced professionals who are also alumni.

The board members are a prominent figures in the community.

\section{Weaknesses}

The D1 program has not been accredited.

The ma'had management is still done by the teachers.

Personnel and education management skills are lacking.

There is no independent business/income to provide financial support.

The administration processes are not yet clarified.

There are only five teachers and administrators in total.

The building still works in cooperation with the high school level, which is reflected in the learning process activities.

The internal factors, namely, the strengths and weakness, are summarized in the IFE matrix. Weights (weight) and rate (rate) are obtained from the FGD results. Table 3 presents the values of IFE for Ma'had ABC.

Table 3 IFE Results for Ma'had ABC

\begin{tabular}{|c|c|c|c|c|c|c|}
\hline \multirow{2}{*}{\multicolumn{2}{|c|}{ Internal strategic factors }} & \multirow{2}{*}{$\begin{array}{l}\text { Weight } \\
\text { (B) }\end{array}$} & \multicolumn{2}{|c|}{$\begin{array}{l}\text { KOORDINAT } \\
\text { SWOT }\end{array}$} & \multicolumn{2}{|c|}{ MATRIKS IE } \\
\hline & & & $\begin{array}{c}\text { Rate } \\
(\mathrm{R})\end{array}$ & $\begin{array}{l}\text { Score } \\
(\mathrm{BxR})\end{array}$ & $\begin{array}{c}\text { Rate } \\
(\mathrm{R})\end{array}$ & $\begin{array}{l}\text { Score } \\
(\mathrm{BxR})\end{array}$ \\
\hline \multicolumn{7}{|c|}{ Strengths: } \\
\hline 1 & $\begin{array}{l}\text { The materials are from a proven } \\
\text { curriculum adopted from LIPIA. }\end{array}$ & $15 \%$ & 4 & 0.6 & 4 & 0.6 \\
\hline 2 & The school already has a mosque. & $5 \%$ & 2 & 0.1 & 2 & 0.1 \\
\hline 3 & $\begin{array}{l}\text { The teachers are experienced } \\
\text { professionals who are also alumni. }\end{array}$ & $10 \%$ & 3 & 0.3 & 3 & 0.3 \\
\hline 4 & $\begin{array}{l}\text { The board members are a prominent } \\
\text { figures in the community. }\end{array}$ & $5 \%$ & 3 & 0.15 & 3 & 0.15 \\
\hline & SUBTOTAL & $35 \%$ & & 1.2 & & 1.2 \\
\hline \multicolumn{7}{|c|}{ Weaknesses: } \\
\hline 1 & The D1 program has not been accredited. & $10 \%$ & -4 & -0.4 & 1 & 0.1 \\
\hline 2 & $\begin{array}{l}\text { The ma'had management is still done by } \\
\text { the teachers. }\end{array}$ & $5 \%$ & -3 & -0.15 & 2 & 0.1 \\
\hline 3 & $\begin{array}{l}\text { Personnel and education management } \\
\text { skills are lacking. }\end{array}$ & $5 \%$ & -4 & -0.2 & 1 & 0.05 \\
\hline 4 & $\begin{array}{l}\text { There is no independent business/income } \\
\text { to provide financial support. }\end{array}$ & $15 \%$ & -4 & -0.6 & 1 & 0.15 \\
\hline 5 & $\begin{array}{l}\text { The administration processes are not yet } \\
\text { clarified. }\end{array}$ & $10 \%$ & -2 & -0.2 & 3 & 0.3 \\
\hline 6 & $\begin{array}{l}\text { There are only five teachers and } \\
\text { administrators in total. }\end{array}$ & $10 \%$ & -4 & -0.4 & 1 & 0.1 \\
\hline 7 & $\begin{array}{l}\text { The building still works in cooperation } \\
\text { with the high school level, which is } \\
\text { reflected in the learning process } \\
\text { activities. }\end{array}$ & $10 \%$ & -4 & -0.4 & 1 & 0.1 \\
\hline \multicolumn{2}{|c|}{ SUBTOTAL } & $65 \%$ & & -2.4 & & 0.9 \\
\hline & TOTAL & $100 \%$ & & -1.2 & & 2.1 \\
\hline
\end{tabular}


An analysis of Opportunities and Threats was also performed. The external factors of Ma'had ABC are summarized into the EFE matrix. Weights (weight) and rate (rate) were obtained from the FGD results.

\section{Opportunities:}

Ma'had ABC is used as a place for learning Arabic in Lombok.

There are not many alternative Arabic language schools similar to Ma'had ABC in Lombok.

There are many Arabic course enthusiasts.

There is an alumni network with professionals who teach at many schools in Lombok and are accepted in LIPIA.

The school is free to attend. Students only pay for their books and can use their money for teaching or preaching programs elsewhere.

Ma'had ABC graduates can continue studying at the S-1 level with curriculum conversion, though this has not been utilized much.

\section{Threats:}

Decreased donations have a major impact on the ma'had operations.

The school is unaccredited.

There is some friction with one of the largest mass organizations in Lombok associated with the existence of Ma'had ABC.

The school is located far from the center of the city mataram, which means its presence remains largely unknown.

Graduates do not receive a certified graduation certificate because there is no accreditation. They just rely on the network.

The building is loaned.

Table 4 External Strategic Factors

\begin{tabular}{|c|c|c|c|c|c|c|}
\hline \multirow{2}{*}{\multicolumn{2}{|c|}{ External strategic factors }} & \multirow{2}{*}{$\begin{array}{l}\text { Bobot } \\
\text { (B) }\end{array}$} & \multicolumn{2}{|c|}{$\begin{array}{l}\text { KOORDINAT } \\
\text { SWOT }\end{array}$} & \multicolumn{2}{|c|}{ MATRIKS IE } \\
\hline & & & $\begin{array}{l}\text { Rating } \\
(\mathrm{R})\end{array}$ & $\begin{array}{l}\text { Nilai } \\
(\text { BxR })\end{array}$ & $\begin{array}{l}\text { Rating } \\
\text { (R) }\end{array}$ & $\begin{array}{l}\text { Nilai } \\
(\text { BxR) }\end{array}$ \\
\hline \multicolumn{7}{|c|}{ Opportunity } \\
\hline 1 & $\begin{array}{l}\text { Ma'had } \mathrm{ABC} \text { is used as a place for } \\
\text { learning Arabic in Lombok. }\end{array}$ & $15 \%$ & 4 & 0.6 & 4 & 0.6 \\
\hline 2 & $\begin{array}{l}\text { There are not many alternative Arabic } \\
\text { language schools similar to Ma'had ABC } \\
\text { in Lombok. }\end{array}$ & $10 \%$ & 4 & 0.4 & 4 & 0.4 \\
\hline 3 & There are many Arabic course enthusiasts. & $5 \%$ & 2 & 0.1 & 2 & 0.1 \\
\hline 4 & $\begin{array}{l}\text { There is an alumni network with } \\
\text { professionals who teach at many schools } \\
\text { in Lombok and are accepted in LIPIA. }\end{array}$ & $5 \%$ & 4 & 0.2 & 4 & 0.2 \\
\hline 5 & $\begin{array}{l}\text { The school is free to attend. Students only } \\
\text { pay for their books and can use their } \\
\text { money for teaching or preaching programs } \\
\text { elsewhere. }\end{array}$ & $5 \%$ & 2 & 0.1 & 2 & 0.1 \\
\hline 6 & $\begin{array}{l}\text { Ma'had ABC graduates can continue } \\
\text { studying at the S- } 1 \text { level with curriculum } \\
\text { conversion, though this has not been } \\
\text { utilized much. }\end{array}$ & $5 \%$ & 3 & 0.15 & 3 & 0.15 \\
\hline & SUBTOTAL & $45 \%$ & & 1.6 & & 1.6 \\
\hline \multicolumn{2}{|c|}{ Threat } & & & & & \\
\hline 1 & $\begin{array}{l}\text { Decreased donations have a major impact } \\
\text { on the } m a \text { 'had operations. }\end{array}$ & $15 \%$ & -4 & -0.6 & 1 & 0.15 \\
\hline 2 & The school is unaccredited. & $10 \%$ & -3 & -0.3 & 2 & 0.2 \\
\hline 3 & $\begin{array}{l}\text { There is some friction with one of the } \\
\text { largest mass organizations in Lombok } \\
\text { associated with the existence of Ma'had } \\
\text { ABC. }\end{array}$ & $10 \%$ & -4 & -0.4 & 1 & 0.1 \\
\hline 4 & $\begin{array}{l}\text { The school is located far from the center } \\
\text { of the city mataram, which means its } \\
\text { presence remains largely unknown. }\end{array}$ & $10 \%$ & -3 & -0.3 & 2 & 0.2 \\
\hline 5 & $\begin{array}{l}\text { Graduates do not receive a certified } \\
\text { graduation certificate because there is no }\end{array}$ & $5 \%$ & -2 & -0.1 & 3 & 0.15 \\
\hline
\end{tabular}




\begin{tabular}{|c|c|c|c|c|c|c|}
\hline & \multirow{2}{*}{ External strategic factors } & \multirow{2}{*}{$\begin{array}{l}\text { Bobot } \\
\text { (B) }\end{array}$} & \multicolumn{2}{|c|}{$\begin{array}{l}\text { KOORDINAT } \\
\text { SWOT }\end{array}$} & \multicolumn{2}{|c|}{ MATRIKS IE } \\
\hline & & & Rating & Nilai & Rating & Nilai \\
\hline & $\begin{array}{l}\text { accreditation. They just rely on the } \\
\text { network. }\end{array}$ & & & & & \\
\hline 6 & The building is loaned. & $5 \%$ & -2 & -0.1 & 3 & 0.15 \\
\hline & SUBTOTAL & $55 \%$ & & -1.8 & & 0.95 \\
\hline & TOTAL & $100 \%$ & & -0.3 & & 2.5 \\
\hline
\end{tabular}

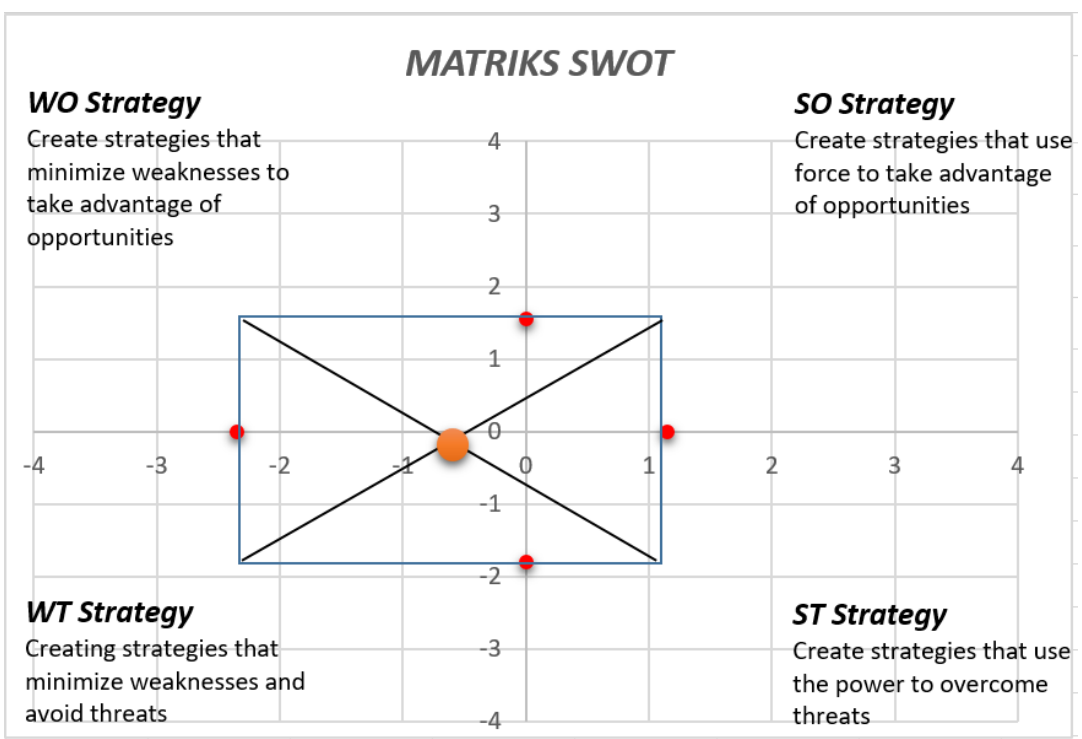

Figure 2. SWOT Results.

Based on these findings, Ma'had $\mathrm{ABC}$ needs to develop short-term strategies that focus on minimizing weaknesses and avoiding threats. These short-term strategies are as follows:

a) Improve teachers' capacity for school management, especially in the financial sector.

b) Improve the administration process.

c) Hire more teaching staff.

d) Develop a network to promote Ma'had ABC.

e) Develop a more exciting method of teaching and learning to increase student participation.

f) Develop donor networks.

Table 5 IE Matrix Results

Matrik IE

\begin{tabular}{|l|l|l|}
\hline \multicolumn{1}{|c|}{4} & $\begin{array}{l}\text { GROWTH } \\
\text { Konsentrasi melalui } \\
\text { integrasi horizontal }\end{array}$ & $\begin{array}{l}\text { GROWTH } \\
\text { Konsentrasi melalui } \\
\text { integrasi vertikal }\end{array}$ \\
\cline { 2 - 4 } 2 & $\begin{array}{l}\text { GROWTH } \\
\text { and/or } \\
\text { STABILITY }\end{array}$ & $\begin{array}{l}\text { STABILITY } \\
\text { Profit Strategy }\end{array}$ \\
\hline LIKUIDASI & $\begin{array}{l}\text { GROWTH } \\
\text { Difersifikasi } \\
\text { Konglomerat }\end{array}$ & $\begin{array}{l}\text { GROWTH } \\
\text { Difersifikasi } \\
\text { Konsentrik }\end{array}$ \\
\hline
\end{tabular}


In addition, Ma'had $\mathrm{ABC}$ needs to develop long-term strategies focused on growth and stability. These strategies are as follows:

a) Open a ma'had in another location in a self-owned building.

b) Develop a program of paid courses.

c) Use digital promotion to extend the range of registration information to cover areas beyond Lombok.

d) Develop an organizational structure of foundations that focus on education and sub-foundations that manage the business as a support to the foundation's operations.

e) Nurture cooperation with donor agencies.

\section{Conclusions}

Based on the results of the assessment, Ma'had $\mathrm{ABC}$ needs to develop long-term strategies that focuses on growth and stability. The school has a good reputation among students, teachers, and surrounding communities. The discussions with stakeholders showed everyone wanted Ma'had ABC to continue growing in spite of the decrease in funds from Saudi Arabia. Moreover, the findings from the SWOT analysis suggest that a business unit should be established in Ma'had ABC so that the school is not too dependent on foreign funds.

\section{References}

ASTM E1529-06. (2004). Standard test methods for determining effects of large hydrocarbon pool fires on structural members and assemblies. West Conshohocken (PA): ASTM International.

Bakis, C. E., Bank, L. C., Brown, V., Cosenza, E., Davalos, J. F., Lesko, J. J., ... \& Triantafillou, T. C. (2002). Fiberreinforced polymer composites for construction - state-of-the-art review. Journal of composites for construction, 6(2), 73-87.

European Committee for Standardization (CEN). (2002). Eurocode 1 actions on structures, Part 1-2: General actions actions on structures exposed to fire. Brussels (Belgium): CEN.

Firefree Coatings, Inc. FF88 Intumescent. Water-based coating for building materials; 2012.<http://www.firefree.com/fireretardant-products/ff88-intumescent-coating.php>. accessed 05.09.12.

Prahalad, C. K., \& Hamel, G. (1994). Competing for the future. (Vol. 25). Boston: Harvard Business School Press.

Jo, B. W., Park, S. K., \& Kim, D. K. (2008). Mechanical properties of nano-MMT reinforced polymer composite and polymer concrete. Construction and building Materials, 22(1), 14-20.

Li, G. (2006). Experimental study of FRP confined concrete cylinders. Engineering Structures, 28(7), 1001-1008 